\title{
A New Deal for Europe? The Commerce Clause as the Solution to Tax Discrimination and Double Taxation in the European Union
}

Charles Edward Andrew Lincoln IV

Follow this and additional works at: https://digitalcommons.pepperdine.edu/jbel

Part of the Comparative and Foreign Law Commons, European Law Commons, and the Taxation-

Transnational Commons

\section{Recommended Citation}

Charles Edward Andrew Lincoln IV, A New Deal for Europe? The Commerce Clause as the Solution to Tax Discrimination and Double Taxation in the European Union, 11 J. Bus. Entrepreneurship \& L. 115 (2018)

Available at: https://digitalcommons.pepperdine.edu/jbel/vol11/iss1/5

This Article is brought to you for free and open access by the Caruso School of Law at Pepperdine Digital Commons. It has been accepted for inclusion in The Journal of Business, Entrepreneurship \& the Law by an authorized editor of Pepperdine Digital Commons. For more information, please contact bailey.berry@pepperdine.edu. 


\title{
A NEW DEAL FOR EUROPE? THE COMMERCE CLAUSE AS THE SOLUTION TO TAX DISCRIMINATION AND DOUBLE TAXATION IN THE EUROPEAN UNION
}

\author{
CHARLES EDWARD ANDREW LINCOLN IV ${ }^{*}$
}

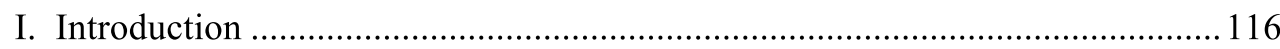

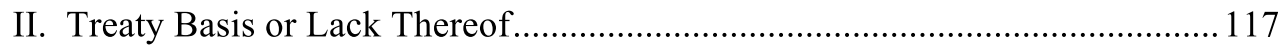

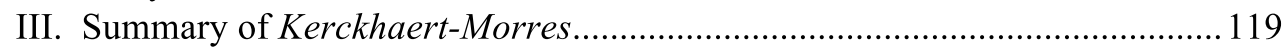

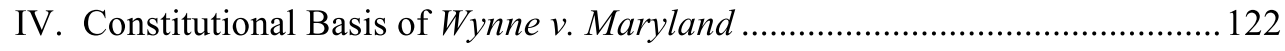

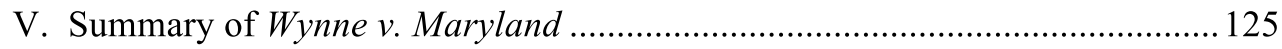

VI. Comparison of Kerckhaert-Morres to Wynne v. Maryland........................... 126

VII. Suggestions for a European Internal Consistency Test ................................127

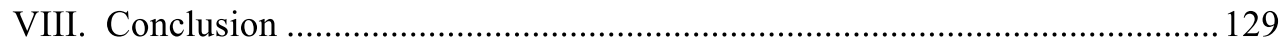

\footnotetext{
* Charles (Charlie) Lincoln is currently pursuing an LL.M. in Taxation at Boston University focusing on U.S. Tax Law_graduation May 2018. This will be Charlie's third law degree. In 2017, he received his Advanced LL.M. degree in International Tax Law at the University of Amsterdam (UvA) in The Netherlands where he completed his Master's Thesis Entitled Amazon, Inc, BEPS and the Method of Risk Allocation: Comparing U.S. Jurisprudence and the OECD Approaches to Risk Allocation in the Post-BEPS Era of Transfer Pricing (Catchy Title, eh?). He graduated from the Texas A\&M University School of Law (Juris Doctor) on Friday May 13 2016, after being awarded his undergraduate baccalaureate from Harvard University in May 2013.

I would like to thank University of Amsterdam (UvA) Professors Dennis Weber and Peter J. Wattel from whom I gained invaluable insights into the structure, functioning, and purposes of the European Union, its economy, and its tax system; Professor Bruno da Silva for his guidance on comparing the United States tax laws with those of the European Union; Professor Joanna Wheeler for setting up a firm basis in international tax systems and the OECD; and Professor William H. Byrnes IV of Texas A\&M University for guiding me - like my very own Major General - from the "Marathon to Waterloo in order categorical" of U.S. law to international law. I would also like to thank Professor Richard T. Ainsworth of Boston University. All these mentors helped me see the confluence and similarities - as well as key differences - of American and European original documents from the Federalist Papers, Commerce Clause analysis, and the Treaty Freedoms for a European Single Market.

Incidentally - though having no personal contact-I would like to thank Lin-Manuel Miranda for his fantastic musical on the life and works of Alexander Hamilton (and, in addition, the, Alexander Hamilton himself as well) that has continually ignited an interest and love for the importance of economics and finance through art - particularly through my study of tax and law.
} 


\section{INTRODUCTION}

The decision by the European Court of Justice (ECJ) in KerckhaertMorres, ${ }^{1}$ allowing double taxation of the same income, led to stagnation in the European internal market. Over the past thirteen years, reservation of competences to member states has created tension between the European Community's goal of a common internal market and the goal to eliminate double taxation. ${ }^{2}$

By exploring and comparing the constitutional basis for taxation in the United States and the treaty basis for taxation in the European Union, one discovers how American New Deal legislation in the 1930s, as a departure from Lochner Era, ${ }^{3}$ could provide the basis for an analogous departure from Kerckharet-Morres in a European New Deal.

The common understanding of the evolution between the Lochner Era and the New Deal denotes the reversal of decades of judicial intervention that prevented states from enacting economic regulation, ${ }^{4}$ with reference to substantive due process rights under the Commerce Clause, and a judicial policy to approve all economic regulations based on a different reading of the U.S. Constitution's Commerce Clause. ${ }^{5}$ As the New Deal in the 1930s brought the

${ }^{1}$ Case C-513/04, Kerckhaert \& Morres v. Belgium, 2006 E.C.R. I-10967.

${ }^{2}$ But see Hegel's theory of dialectical processes in the resolution of conflict over power. Charles Edward Andrew Lincoln IV, Hegelian Dialectical Analysis of U.S. Voting Laws, 42 U. DAYTON L. REV. 87, 91 (2017).

${ }^{3}$ See Lochner v. New York, 198 U.S. 45 (1905).

${ }^{4}$ The Texas Supreme Court recently summarized Lochner by stating:

Basically, then, during the "Lochner [E]ra," substantive due process was a touchstone by which courts analyzed both the purpose and the effect of governmental economic regulation by scrutinizing them with a somewhat equivocal deference to the legislative body's pronounced purpose for a law and its choice of the method embodied in the law to achieve that purpose.

Patel v. Texas Dep't of Licensing \& Regulation, 469 S.W.3d 69, 85-86 (Tex. 2015). Cf. RANDY E. BARNETT, RESTORING THE LOST CONSTITUTION: THE PRESUMPTION OF LIBERTY (2004).

${ }^{5}$ The United States Supreme Court pronounced that:

$[R]$ egulatory legislation affecting ordinary commercial transactions is not to be pronounced unconstitutional unless in the light of the facts made known or generally assumed it is of such a character as to preclude the assumption that it rests upon some rational basis ....

United States v. Carolene Products Co., 304 U.S. 144, 152 (1938). "Ensuing federal decisions tracked Carolene Products' guidance that economic regulatory laws were presumed to be constitutional absent evidence or judicially known facts demonstrating that no rational basis existed for the regulation." Patel, 469 S.W.3d at 86. 
United States out of the Lochner Era, a similar New Deal should be conducted in the European Union to bring it out of the Kerckhaert-Morres era.

The European Union should adopt a true federal system akin to that of the United States, avoid pretending to maintain a Hamiltonian ${ }^{6}$ system, or avoid fiscal coherence issues all together for a non-common market. The Lochnerstyle Kercharet-Morres era damages the unity of the "federal" system of the European Union.

The European Union exhibits some markers of a federal system of finance, ${ }^{7}$ such as a national bank in the European Union Bank. However, a common codified system of taxation enacted through a directive or new multi-lateral treaty negotiation amongst states, such as the 1916 Constitutional Amendment or the United States Commerce Clause, could lead to the creation of a proper federal system in the European Union.

\section{TREATY BASIS OR LACK THEREOF}

The ultimate goal of the European Union is set forth in Articles 2-6 of the Treaty on European Union (TEU). ${ }^{8}$ To reach these goals, Articles 3 and 4 indicate that "the establishment of an internal market and of an economic monetary union," are necessary. ${ }^{9}$ There are two ways in which the ultimate goal of a unified internal market of the European Union can come about: positive integration and negative integration. ${ }^{10}$

Article 115 of the Treaty on the Functioning of the European Union (TFEU) is the legal basis for harmonization ${ }^{11}$ of direct taxes through positive

${ }^{6}$ Compare Joyce O. Appleby, Foreword to The Revolutionary Writings OF ALEXANDER HAMILTON vii, viii-x (Richard B. Vernier ed., 2008) (discussing the skill and impact of Hamilton's writings), with Lin-Manuel Miranda, Hamilton: An American Musical, Cabinet Battle \#1, (Atlantic Recording Corp. 2015) (in order to be "aggressive and competitive," such as the musical), and Richard F. Duncan, Justice Scalia and the Rule of Law: Originalism vs. the Living Constitution, 29 REgENT U. L. REV. 9, 33, n.169 (2017).

${ }^{7}$ See Kevin Foley, The Civil War and the National Banking System, CoINWEEK (Nov. 13, 2015), https://coinweek.com/education/the-civil-war-and-the-national-banking-system-the-birth-ofnational-bank-notes/.

${ }^{8}$ Ben J.M. TERra \& Peter J. WATtel, European TAX LaW 3 (3d ed. 2012). See also Servaas van Thiel, Symposium on Corporate Tax Policy in the European Union: The Direct Income Tax Case Law of the European Court Of Justice: Past Trends and Future Developments, 62 TAX L. REV. 143. (2008) ("[s]ince the early 1950s Europe has been engaged in a politically motivated integration process that seeks to tie the economic, social, and political structures of the European States so closely together that they cannot afford to enter into armed conflict with each other.").

${ }^{9}$ TERRA \& WATTEL, supra note 8. See Georg W. Kofler, Ruth Mason, Double Taxation: A European "Switch in Time?", 14 COLUM. J. EUR. L. 63 (2007-2008) ("With twenty-seven countries and over 450 million inhabitants, the European Union is the largest common market in the world."). Id. at 63 .

${ }^{10}$ TERRA \& WATTEL, supra note 8.

${ }^{11}$ Professor Jarrod Tudor stated:

There are several advantages to the free movement of capital including an 
integration. ${ }^{12}$ However, the basis of directive may only be adopted through a unanimous European Council. ${ }^{13}$ Harmonization of direct taxes does not exist in Article 114 TFEU. ${ }^{14}$ In the EC Treaty ${ }^{15}$ (the Treaty), Article 293 contained a provision urging countries to negotiate the abolition of double taxation. ${ }^{16}$ The TFEU does not have such a provision, as it was only a political declaration. ${ }^{17}$ However, the key is that the articles in the Treaty acting as positive integration or actions through the Council are not - as otherwise would be expected - what is leading to harmonization of direct taxes. ${ }^{18}$

Negative integration through the Fundamental Freedoms is one of the main impediments to abolishing double taxation. ${ }^{19}$ The basis for the Fundamental Freedoms being having the same level as European Treaties comes from Internationale Handelsgesellschaft. ${ }^{20}$ Since Internationale Handelsgesellschaft,

overall increase in the supply of capital within the EU, greater choice in financing packages for firms operating within the EU, fewer economic disruptions, and the maintenance of equal production conditions. Ironically, Article 63 (ex 56, 73b) does not define the concept of free movement of capital. The doctrine of non-discrimination also applies to the guarantee of free movement of capital. Pursuant to the non-discrimination doctrine, out-ofstate capital must enjoy the same treatment as in-state capital. However, the non-discrimination doctrine does not interfere with the Member State's ability to regulate capital, but merely requires the Member State to regulate the capital equally. Although the basic rule under Article 63(1) is that Member States must respect the free movement of capital, Member States are given an opportunity under Article 65 (ex 58, 73d) to defend restrictions on the free movement of capital.

Jarrod Tudor, The Free Movement of Capital in Europe: Is the European Court of Justice Living Up to Its Framers' Intent and Setting an Example for the World?, 42 OHIO N.U. L. REV. 195, 201 (2015).

${ }^{12}$ Lukasz Adamczyk \& Alicja Majdańska, The Sources of EU Law Relevant for Direct Taxation, in INTRODUCTION TO EUROPEAN TAX LAW ON DiRECT TAXATION 14 (Michael Lang et al. eds., 2008).

${ }_{13}^{13} I d$.

${ }^{14} \mathrm{Id}$.

${ }^{15}$ Treaty Establishing the European Economic Community, Mar. 25, 1957, amended by Treaty on the Functioning of the European Union, June 7, 2016, O.J. C 202/1.

${ }^{16}$ Algirdas Šemta, Tax Policy Work Programme, EUROPEAN COMM'N TAXATION \& CUSTOMS UNION (Feb. 16, 2010), http://ec.europa.eu/archives/commission_2010-2014/semeta/headlines/speec hes/2010/02/speech_1602b.pdf. See generally, Adamczyk \& Majdańska, supra note 12.

${ }^{17}$ Case C-336/96, Gilly v. Directeur des Services Fiscaux du Bas-Rhin, 1998 E.C.R. I-2793 at ๆ 17. See generally Adamczyk \& Majdańska, supra note 12.

${ }^{18}$ Adamczyk \& Majdańska supra note 12, at 15.

${ }^{19}$ Id. See also Michael LANG, InTRODUCTION to EUROPEAN TAX LAW ON DireCt TAXATION 15 (Linde Verlag, 2008); Kofler \& Mason, supra note 9 ("International public law imposes few limits on countries' tax powers other than the requirement of jurisdictional nexus."); Sjoerd Douma, The Three Ds of Direct Tax Jurisdiction: Disparity, Discrimination and Double Taxation, 46 EuR. TAX'N 522, 523 (2006); see also Dennis Weber, Tax Avoidance and the EC Treaty Freedoms 1 (2005).

${ }^{20}$ Case 11/70, Internationale Handelsgesellschaft, mbH v. Einfuhr, 1970 E.C.R., 1125. See also Adamczyk \& Majdańska, supra note 12, at 15. 
the connection between European Union fundamental rights and taxation has grown, culminating in the Charter of Fundamental Rights. ${ }^{2}$

However, as Kerckhaert-Morres pointed out, "the [c]ourt cannot prohibit disparities . . . between national laws ${ }^{22} \ldots$ nor the 'exercise in parallel' of two taxing points." ${ }^{23}$ This is because such differences "can only be solved by making jurisdictional priority choices, i.e. political choices." 24

\section{SUMMARY OF KERCKHAERT-MORRES}

The main issue in Kerckhaert-Morres was whether unrelieved double taxation on capital - in that case, dividends-was a violation of the free movement of capital. ${ }^{25}$

${ }^{21}$ Adamczyk \& Majdańska, supra note 12, at 17; see also CJEU, 1 March 2011, Case C467/09, Chartry, OJ C 37 of 13 February 2010, at 3-3.

${ }^{22}$ It is also clear that even if national laws were harmonized, there could still be double taxation. See Case C-385/00, De Groot v. Staatssecretaris van Financien, 2002 E.C.R. 1-11819 (holding that the Netherlands' practice of reducing a resident taxpayer's personal deductions in proportion to the taxpayer's foreign source income, which was exempt from tax in the Netherlands, violated the taxpayer's freedom of movement of workers because the other states in which he worked did not grant him a proportional increase in personal deductions); Kofler \& Mason, supra note 9. It is interesting to note that De Groot may have also implied that the combination of the Dutch fiscal unity and the participation exemption with respect to incoming foreign dividends could be a violation of State Aid rules.

${ }^{23}$ Research Handbook on the LaW of the EU's Internal Market 47, 335 (Panos Koutrakos \& Jukka Snell eds., Edward Elgar Publishing, 2017).

${ }^{24} \mathrm{Id}$.

${ }^{25}$ Case C-513/04, Kerckhaert \& Morres v. Belgium, 2006 E.C.R. I-10967, 甲甲 14-21.

"Consolidated Version of the Treaty on the Functioning of the European Union art. 63, EU, Dec. 13, 2007, 51 O.J. E.U. 2008/C 115/1 (the TFEU). Article 63 (also known as art. 56 EC or EC Treaty, art. 73b) of the TFEU reads:

1. Within the framework of the provisions set out in this Chapter, all restrictions on the movement of capital between Member States and between Member states and third countries shall be prohibited.

2. Within the framework of the provisions set out in this Chapter, all restrictions on payments between Member States and between Member States and third countries shall be prohibited.

Article 65, also known as art. 58 EC or EC Treaty, art. 73d, states:

1. The provisions of Article 63 shall be without prejudice to the right of Member States:

(a) to apply the relevant provisions of their tax law with distinguish between taxpayers who are not in the same situation with regard to their place of residence or with regard to the place where their capital is invested;

(b) to take all requisite measures to prevent infringements of national law and regulations, in particular in the field of taxation and the prudential supervision of financial institutions, or to lay down procedures for the declaration of capital movements for purposes of administrative or statistical information, or 
The facts of the case involved a couple, Mark Kerckhaert and Bernadette Morres, the Kerckhaert-Morreses, who lived in Belgium. ${ }^{26}$ In 1995 and 1996, the couple received dividends from a French resident company named Eurofers SARL ${ }^{27}$ France maintained a withholding tax of $15 \%$ when the dividends left France. ${ }^{28}$ Belgium did not apply the credit system for any taxes paid on French dividend withholding taxes. ${ }^{29}$ Belgium taxed dividends at $25 \%$ on the corporate level domestically without any double tax relief. ${ }^{30}$ Thus, the KerckhaertMorreses were taxed at a greater rate than if the dividends originated in Belgium. ${ }^{31}$

The Belgian court requested a preliminary hearing from the ECJ to determine whether the imposition of double taxation violated Article 53 of the TFEU, stating that the rule was "interpreted as prohibiting a restriction resulting from a provision in the income tax legislation of a Member State," as promulgated by Belgium "dividends from resident companies and dividends from companies resident in another Member State to the same uniform tax rate, without in the latter case providing for the imputation of tax levied at source in that other Member State." ${ }^{32}$ The Commission inferred:

Belgium would nevertheless be responsible under EC law to credit French withholding, because Belgium entered into a tax treaty with France that allowed France to withhold on dividends paid from French companies to Belgian shareholders in contemplation of a credit by Belgium . . .

to take measures which are justified on grounds of public policy or public security.

2. The provisions of this Chapter shall be without prejudice to the applicability of restrictions on the right of establishment which are compatible with the Treaties.

3. The measures and procedures referred to in paragraphs 1 and 2 shall not constitute a means of arbitrary discrimination or a disguised restriction on the free movement of capital and payments as defined in Article 63." (emphasis added)

See generally Jarrod Tudor, The Free Movement of Capital in Europe: Is the European Court of Justice Living Up to Its Framers' Intent and Setting an Example for the World?, 42 OHIO N.U.L. REV. 195, 201-02 n.55, n.61 (2015).

${ }^{26}$ Kerckhaert, 2006 E.C.R. I-10967, 99.

${ }^{27} \mathrm{Id}$.

${ }^{28} \mathrm{Id}$.

${ }^{29} I d$. at 10.

${ }^{30} I d$. at $\uparrow \uparrow 5,7$.

${ }^{31} \mathrm{Id}$. at $\uparrow 11$.

${ }^{32}$ Case C-513/04, Kerckhaert, 2006 E.C.R. 1-10967, at 14. Most tax cases arise before the ECJ as preliminary ruling requests from national courts. See RUTH MASON, PRIMER ON DIRECT TAXATION IN THE EUROPEAN UNION 17-21 (2005). Under Article 243 EC, national courts may (and in some cases must) refer to the ECJ questions relevant to cases pending before them that require the interpretation of EC law. The ECJ's decisions on preliminary ruling requests bind national courts to that interpretation. See EC Treaty, supra note 5, art. 234.” Kofler \& Mason, supra note 9. 
[thereby relying] on existing tax treaties to allocate responsibility for relieving juridical double taxation that violates the fundamental freedoms. ${ }^{33}$

The ECJ, looking to Article 73b(1) of the EC Treaty-Article 56(1) of the current EC Treaty - did not prevent a Member State from taxing income dividends from companies in other Member States at the same uniform rate of taxation without providing double tax relief. ${ }^{34}$

Advocate General Geelhold reasoned:

A potential disadvantage for Belgian residents receiving French dividends would not ... result from any breach of the [EC] Treaty ... [because] the free movement provisions of the Treaty ... do not as such oblige home states to relieve juridical double taxation resulting from the dislocation of [a] tax base between two Member States. ${ }^{35}$

Geelhold's view was that "juridical double taxation was thus a 'quasirestriction,' and as such it 'may only be eliminated through the intervention of the Community legislator."”36

The ECJ stated that EU Treaty Freedoms do not preclude Member States from "parallel exercise of taxing jurisdiction," even if it leads to double taxation, as long as neither state treats the cross-border situation less favorably than a comparable, purely domestic situation. ${ }^{37}$ This is because such a restriction is not a restriction of the free movement of capital. ${ }^{38}$

"[I]n Kerckhaert, the conclusion was that there was no violation of EU law, and this conclusion was reached because there was no differentiated treatment of comparable situations." ${ }^{39}$ The ECJ concluded that member states are not obliged to relieve double taxation on cross-border income within the European Union

\footnotetext{
${ }^{33}$ Kofler \& Mason, supra note 9. See also Kerckhaert, 2006 E.C.R. 1-10967, \ 38 (opinion of Advocate General Geelhoed).

${ }^{34}$ See Weber, DenNis, European Direct Taxation: Case LaW and Regulations, 85 (3d ed. 2011). ("[The EC Treaty] does not preclude legislation of a Member State, such as Belgian tax legislation, which in the context of tax on income, makes dividends from shares in companies established in the territory of that State and dividends form shares in companies established in another Member State subject to the same uniform rate of taxation, without providing for the possibility of setting off tax levied by deduction at source in that other Member State.").

${ }^{35}$ Kerckhaert, 2006 E.C.R. 1-10967, ๆฯ 29, 30 (Apr. 6, 2006) (opinion of Advocate General Geelhoed).

${ }^{36}$ Kofler \& Mason, supra note 9, at 63, 78.

${ }^{37}$ Kerckhaert, 2006 E.C.R. 1-10967, ๆ 25.

${ }^{38} \mathrm{Id}$.

${ }^{39}$ Carlo Garbarino, The Development of the Comparability Analysis by the Court of Justice of the European Union in the Context of Capital Income Taxation, 21 COLUM. J. EUR. L. 451, n. 164 (2015).
} 
and noted that EU law "does not lay down any general criteria for the attribution of areas of competence between the Member States in relation to the elimination of double taxation within the Community." 40

The ECJ ruled this way because the current treaty structure of the EU does not confer the authority to impose methods of taxing cross-border income. ${ }^{41}$ This essentially means that "the ECJ determined that it is not a matter of EU Law[,] but rather of each [M]ember [S] tate to take the appropriate measures to grant relief for juridical double taxation." $" 42$

As a meta-analysis stated, the key point to Kerckhaert-Morres is the "comparability standard." whether the two positions are comparable from the point of view of the object and purpose of the impugned national tax measure . . assumption of taxing jurisdiction is national sovereignty, but the exercise of the jurisdiction so assumed is subject to Court scrutiny." need to credit foreign dividend withholding tax on foreign dividends received by its residents again the Belgian income tax to which these residents were subject for foreign dividends, as Belgium neither subjected both domestic and foreign dividends to a final tax at the same rate." taxes, that "the [c]ourt is a balancing artist between the interests of the single internal market and the 2[8] legitimate interests of separate Member States to protect their tax bases, rather than Montesquieu's bouche qui pronnce les paroles de la loi.",46

\section{CONSTITUTIONAL BASIS OF WYNNE V. MARYLAND}

The source for limiting state taxation in the United States Constitution comes from the Commerce Clause as an affirmative command to Congress " $[\mathrm{t}] \mathrm{o}$ regulate Commerce with foreign Nations, and among the several States, and with the Indian Tribes. ${ }^{, 47}$ But in addition to this affirmative command, there is a

40 Case C-128/08, Jacques Damseaux v. Belgian State, 2009 E.C.R. I-06823. See also Kerckhaert, 2006 E.C.R. 1-10967, ๆ 22. See also Case C-336/96, Gilly v. Directeur des Services Fiscaux du Bas-Rhin, 1998 E.C.R. I-2793, 24 ("The Member States are competent to determine the criteria for taxation on income and wealth with a view to eliminating double taxation.").

${ }^{41}$ Ruth Mason \& Michael S. Knoll, What Is Tax Discrimination?, 121 YALE L.J. 1014, 1075 (2012).

${ }^{42}$ Hugo A. Hurtado, Is Latin American Taxation Policy Appropriate for Promoting Foreign Direct Investment in the Region?, 31 NW. J. INT'L L. \& BuS. 313, 357 (2011).

${ }^{43}$ TERRA \& WATTELL, supra note 8 , at 892-93.

${ }^{44}$ Id. at 892. See Case C-307/97Campaign de Saint-Gobain v. Finanzamt Aachen-Innenstadt, 1999 ECR I-6163.

${ }^{45}$ TERRA \& WATTELL, supra note 8 , at 893.

${ }^{46} I d$. at 37. See Montesquieu, De L'Esprit des Lois [The Spirit of the Laws] Livre XI Chapitre VI bk. XI, ch. 6 (1748).

${ }^{47}$ U.S. CONST. art. I, $\S 8$, cl. 3. For a general discussion on the structure of the U.S. Constitution, see Charles Lincoln, A Structural Etiology of the U.S. Constitution, 43 J. LEGIS. 122 (2016). 
negative command "[the Supreme Court] has consistently held this language to contain a [] negative command, prohibiting certain state taxation even when Congress has failed to legislate on the subject."

The United States Supreme Court stated that the dormant Commerce Clause "denies the States the power unjustifiably to discriminate against or burden the interstate flow of articles of commerce." 49 The negative aspect of the Commerce Clause "exists because the Framers intended to (1) avoid the economic isolation that hampered relations among the states under the Articles of Confederation and (2) create an economic environment where the 'several states must sink or swim together.", 50

In 1888 , the Court held that "exemption of interstate and foreign commerce from state regulation does not prevent the state from taxing the property of those engaged in such commerce located within the state as the property of other citizens is taxed," meaning that the commerce clause had a "negative sweep" that places limits on state taxation. ${ }^{51}$ The Supreme Court stated "it was irrelevant if intrastate businesses faced identical tax burdens. ${ }^{, 52}$

In $1905,{ }^{53}$ U.S. Commerce Clause interpretation turned into the so-called Lochner era. Describing the Lochner ${ }^{54}$ era, Justice Breyer in 2011 quoted Justice

${ }^{48}$ Okla. Tax Comm'n v. Jefferson Lines, Inc., 514 U.S. 175, 179 (1995) (citing Quill Corp. v. North Dakota, 504 U.S. 298, 309 (1992)) "Two Justices on the current Supreme Court, however, repudiate the dormant Commerce Clause. Justice Scalia will apply dormant Commerce Clause doctrine only when stare decisis compels the result, while Justice Thomas would 'entirely discard the Court's negative Commerce Clause jurisprudence." Id. See also Michael Fader, May States Double Tax Their Residents' Incomes? The Dormant Commerce Clause in Maryland State Comptroller of the Treasury v. Wynne, 68 TAX L. 367, 370 n.26 (2015); Dep't of Revenue of Ky. v. Davis, 553 U.S. 328, 359-62 (2008). (Asserting the dormant Commerce Clause has no Constitutional basis).

${ }^{49}$ Or. Waste Sys., Inc. v. Dep't of Envtl. Quality, 511 U.S. 93, 98 (1994).

${ }^{50}$ Fader, supra note 48 , at 370 . The first prong has its source in Davis, 553 U.S. 328, at 338. The second prong has its source in Baldwin v. G.A.F. Seelig, Inc., 294 U.S. 511, 523 (1935).

${ }^{51}$ Leloup v. Port of Mobile, 127 U.S. 640, 649 (1888). See also James F. Murtha, Esq., Taxing Colonel Sanders: Re-Examining Constitutional Nexus Through the Lens of KFC v. Iowa, 35 W. NEW ENG. L. REV. 55, 58 (2013); see generally, Fader, supra note 48.

${ }^{52}$ Fader, supra note 48, at 370 (citing Robbins v. Taxing Dist. of Shelby Cnty., Tenn., 120 U.S. 489, 497 (1887). The Supreme Court in 1995, referring to this era stated, "the Court held the view that interstate commerce was wholly immune from state taxation "in any form." Oklahoma Tax Comm'n v. Jefferson Lines, Inc., 514 U.S. 175, 180 (1995).

53 "Except for a few occasional references, the Court made scant use of substantive due process concepts until after the Civil War. Although the Slaughter-House Cases forestalled the use of the fourteenth amendment as a substantive restraint on state legislation, laissez-faire views became increasingly apparent, especially in dissenting opinions. By 1887, the movement of the Court was clearly visible." Resurrecting Economic Rights: The Doctrine of Economic Due Process Reconsidered, 103 HARV. L. REV. 1363 (1990) [hereinafter Resurrecting Economic Rights]. For further information, see generally Douglas S. Broyles, Have Justices Stevens and Kennedy Forged A New Doctrine of Substantive Due Process? An Examination of McDonald v. City of Chicago and United States v. Windsor, 1 TEX. A\&M L. REV. 129 (2013).

${ }^{54}$ Lochner v. New York, 198 U.S. 45 (1905). 
Rehnquist in Central Hudson ${ }^{55}$ stating that "it was common practice for this Court to strike down economic regulations adopted by a State based on the Court's own notions of the most appropriate means for the State to implement its considered policies." 56 These decisions were analyzed through the substantive due process doctrine whereby the Court "invalidated many federal and state statutes on economic due process grounds" as a protection for economic liberties. ${ }^{57}$

The 1995 United States Supreme Court described a change in U.S. Commerce Clause analysis in relation to taxation during the Lochner era. ${ }^{58}$ The Court explained that the Commerce Clause analysis over time

gave way in time to a less uncompromising but formal approach, according to which, for example, the Court would invalidate a state tax levied on gross receipts from interstate commerce, ${ }^{59}$. . but would allow a tax merely measured by gross receipts from interstate commerce as long as the tax was formally imposed upon franchises, ... or "in lieu of all taxes upon [the taxpayer's] property.",60

This disposition of U.S. case law in the Lochner era seems akin to the current state of the European Union case law in relation to double taxation. Indeed, it seems identical to the decision in Kerckhaert-Morres, because the United States in the early twentieth century allowed for double taxation in certain scenarios, and Europe currently allows for states to impose double taxation in a broader sense, even if it harms the internal market.

However:

[t]he Court later retreated from this position in part because it became convinced that protecting liberty meant more than just enforcing laissez-faire, [when] the Court the fourteenth amendment as guarding "liberty in a social organization which requires the protection of law against the evils which menace the health, safety, morals and welfare of the people." 61 (1980).

${ }^{56}$ Sorrell v. IMS Health Inc., 564 U.S. 552, 585 (2011).

${ }^{57}$ Resurrecting Economic Rights, supra note 53, at 1366.

${ }^{58}$ Oklahoma Tax Comm' $n$, supra note 48, at 180.

${ }^{59}$ Citing New Jersey Bell Telephone Co. v. State Bd. of Taxes and Assessments of N.J., 280 U.S. 338 (1930); Meyer v. Wells, Fargo \& Co., 223 U.S. 298 (1912); Oklahoma Tax Comm'n v. Jefferson Lines, Inc., 514 U.S. 175, 180 (1995).

${ }^{60}$ Citing United States Express Co. v. Minnesota, 223 U.S. 335, 346, 32 S.Ct. 211, 215, 56 L.Ed. 459 (1912). See generally Lockhart, Gross Receipts Taxes on Interstate Transportation and Communication, 57 HARV. L. REV. 40, 43-66 (1943); see also Oklahoma Tax Comm'n, supra note 48.

${ }^{61}$ Resurrecting Economic Rights, supra note 53, at 1371. 
Indeed, this may have been the most appropriate idea for the time, because "[n]umerous studies have proven that governmental regulation of the economy is not only inefficient, but also often harmful to consumers, workers, and owners.",62

In the 1930s and 1940s, beginning in 1938 with J.D. Adams Mfg. Co. v. Storen., ${ }^{63}$ the Supreme Court started moving from the Lochner era tax policy. Wynne summed up the cases as when "the Court struck down a state tax scheme that might have resulted in the double taxation of income earned out of the State and that discriminated in favor of intrastate over interstate economic activity." 64

\section{SUMMARY OF WYNNE V. MARYLAND}

In the United States Supreme Court case Wynne v. Maryland, the Court applied the "Internal Consistency Test" to cross-border taxation by a State in relation to federal income tax leading to the complete opposite decision from Kerckhaert-Morres with almost identical facts. ${ }^{65}$

The Maryland tax system contained two levels: a statewide level of personal income tax, and a county level income tax. ${ }^{66}$ The state level had a worldwide reach. ${ }^{67}$ The state level provided a credit for taxes paid in other states. ${ }^{68}$ However, the county tax system did not provide a tax credit or any other relief. ${ }^{69}$ This resulted in double taxation in another state, and again in Maryland on the county level. ${ }^{70}$

The facts of the case involve the Wynnes, residents of Maryland, who earned income in other states and were subject to double taxation in Maryland at the county level. ${ }^{71}$ Justice Alito's decision stated that the rule for determining whether the Dormant Commerce Clause was violated was if the:

(1) tax schemes ... inherently discriminate against interstate

${ }^{62}$ Id. at 1371-72 n.70 (citations omitted). See also STEPHEN BREYER, REGULATION AND ITS REFORM 1-4 (1982) (summarizing criticisms of government regulation). Many studies illustrate the negative effects of regulation in specific industries. See, e.g., Robert W. Crandall, Regulation of Television Broadcasting, REGULATION Jan.-Feb., 31, 31 (1978); Peter Huber, Electricity and the Environment: In Search of Regulatory Authority, 100 HARV. L. REV. 1002 (1987); Theodore E. Keeler, Airline Regulation and Market Performance, 3 BELl J. ECON. \& MGMT. SCI. 399 (1972); Reuben A. Kessel, Economic Effects of Federal Regulation of Milk Markets, 10 J.L. \& Econ. 51 (1967).

${ }_{63}^{63}$ J.D. Adams Mfg. Co. v. Storen, 304 U.S. 307, 308 (1938).

${ }_{64}^{64}$ Comptroller of Treas. of Maryland v. Wynne, 135 S. Ct., 1787, 1795 (2015).

${ }^{65}$ Id. at 1791 .

${ }^{66} \mathrm{Id}$, at $1792-93$.

${ }^{67} \mathrm{Id}$.

${ }^{68} \mathrm{Id}$.

${ }^{69} I d$.

${ }^{70} \mathrm{Id}$.

${ }^{71}$ Wynne, 135 S. Ct. 1787, at 1792-93. 
commerce without regard to the policies of other states, and [the] (2) tax schemes . . . create disparate incentives to engage in interstate commerce (and sometimes result in double taxation) only as a result of the interaction of two different but discriminatory and internally consistent schemes. ${ }^{72}$

The Court reasoned that tax schemes that fail the internal consistency test will fall into the first category, not the second: "[A]ny cross-border tax disadvantage that remains after application of the [test] cannot be due to tax disparities[,]" but is instead attributable to the taxing state's discriminatory policies alone. ${ }^{73}$ Essentially, the internal consistency test states that if every state used the same tax system, commerce would be taxed the same as commerce entirely within one state. ${ }^{74}$

Given that Maryland did not offer a credit to Maryland residents against the county tax for taxes paid in other states even when Maryland imposed a county tax on non-residents earning income in Maryland, the Court decided that the tax system did not pass the "internal consistency" test. ${ }^{75}$

\section{COMPARISON OF KERCKHAERT-MORRES TO WYNNE V. MARYLAND}

"The free trade provisions of the United States Constitution and the EC Treaty have broadly similar aims: to remove legal disincentives to investment across state borders." ${ }^{, 76}$ The United States Supreme Court and the ECJ seem to have different concepts of discrimination of the cross-border situation as compared to the domestic situation. ${ }^{77}$ Comparatively, "[t]he ECJ . . . has held that nondiscrimination both permits exemption and does not require tax rate harmonization., 78

Analyzing Wynne, Professor Ruth Mason stated, "[t]he United States has a true federal fiscal system. Long-standing debates in the United States concern whether the federal or state government is better suited to assess certain taxes and make certain expenditures." 79

Indeed, Professor Mason pointed out that,

[D]ue to the fact that the EU central government largely lacks tax powers and has a very small budget, vertical federalism

${ }^{72}$ Id. at 1802 .

${ }^{73} \mathrm{Id}$.

${ }^{74} \mathrm{Id}$.

${ }^{75} \mathrm{Id}$.

${ }^{76}$ Kofler \& Mason, supra note 9.

${ }^{77}$ Id.

${ }^{78}$ Ruth Mason \& Michael S. Knoll, What Is Tax Discrimination?, 121 YALE L.J. 1014, 1094 (2012)

${ }^{79}$ Ruth Mason, Common Markets, Common Tax Problems, 8 FLA. TAX REV. 599, 619 (2007). 
debates in the European Union tend not to focus on taxing and spending issues. Instead, the principal vertical federalism issue for European taxation concerns tax relations with third countries. There is considerable debate about the scope of the European Union's "external tax competence," its ability to negotiate tax treaties and other tax agreements with third countries. Although it is clear that in the United States the power to enter into tax treaties with other countries belongs to the federal government, questions arise over the extent to which federal tax policy and foreign policy limit state tax powers. ${ }^{80}$

United States case law in the Lochner era is akin to the current state of European Union case law in relation to double taxation. Indeed, it seems identical to the decision in Kerckhaert-Morres when one considers the fact that the United States in the early twentieth century permitted double taxation in certain scenarios and Europe currently permits states to impose double taxation in a broader sense, even if it harms the internal market. ${ }^{81}$

\section{SUGgESTIONS FOR A EUROPEAN INTERNAL CONSISTENCY TEST}

Professor Ruth Mason stated "[j]udicial self-restraint seems inappropriate where "the fact that a taxable event might be taxed twice is the most serious obstacle there can be to people and their capital crossing internal borders." ${ }^{\prime \prime 2}$

[T] he ECJ [seems] to adhere to the OECD view that the source principle prevails over the residence principle . . . and that therefore, the residence State should provide double taxation relief source country entitlement, but in recent cases such as Kerckhaert-Morres, the Court held that the Treaty Freedoms are not capable of preventing international double taxation as a result of "exercise in parallel by two member States of their fiscal sovereignty," meaning the overlap of source taxation

${ }^{80} I d$.

${ }^{81} I d$.

${ }^{82}$ Kofler \& Mason, supra note 9, at 79-80; Case C-376/03, D. v. Inspecteur van de Belastingdienst, 2005 E.C.R. 1-5821, If 85 (2004) (opinion of Advocate General Ruiz-Jarabo Colomer). The Swiss experience demonstrates that double taxation can be resolved judicially, as the Swiss courts have had to give meaning to the constitutional prohibition of double cantonal taxation. Id. Also, the Commerce Clause of the United States Constitution limits the ability of states to impose double taxation, at least where double taxation results from internally inconsistent state legislation. Id. For more on the internal consistency test under United States law, see Walter Hellerstein, Is "Internal Consistency" Foolish?: Reflections on an Emerging Commerce Clause Restraint on State Taxation, 87 MiCH. L. REV. 138 (1988). 
and residence taxation. ${ }^{83}$

Is it reasonable to say that the EU states may balkanize against each other in terms of tax? Such uncooperative rules raise further issues, given the fact that the ECJ permitted the type of cross-border taxation the United States prohibited in Wynne.

This seems to lead to a contrasting dialectic of different outcomes on similar facts. It also provides a viewpoint into the ECJ concept of discrimination, because the ECJ has allowed double taxation in cross-border states as long as it meets the four-point test and does not discriminate. ${ }^{84}$ In terms of the United States' case, it seems as if the ECJ/EU allows for economic impediments in terms of taxation as long as the member states do not discriminate against other states. ${ }^{85}$

The ECJ should adopt the internal consistency test for a more uniform approach to EU Tax Law. In fact, "[t]he ECJ has acknowledged that one of the consequences of creating the common market was tax competition among the member states, and, more generally, that creating a robust regulatory marketplace was an explicit aim of the common market." 86

The ECJ even admitted in other case law, "[a]s the Commission rightly observed, such compensatory tax arrangements prejudice the very foundations of the single market." ${ }^{87}$ Thus, tax discrimination does create a net disadvantage for the taxpayer and possibly affects the common market by undermining tax competition. ${ }^{88}$

Indeed, supporting this statement is the phenomenon that tax revenue is shifted from an EC-law compliant state to a discriminating state "when one state compensates for the tax discrimination of another," which appears unfair and

${ }^{83}$ TERRA \& WATTELL, supra note 8 , at 212. For a discussion on corporate residency, see Charles Edward Andrew Lincoln IV, Is Incorporation Really Better Than Central Management and Control for Testing Corporate Residency? An Answer to Corporate Tax Evasion and Inversion, 43 OHIO N.U.L. REV. 359, 365 (2017). Cf. Charles Lincoln, The Myth of "Separate Enterprises" in International Taxation: Approaches to Attribution of Profits to Permanent Establishments, 22 TRINITY L. REV. 30 (2017).

${ }^{84}$ See, e.g., Kofler \& Mason, supra note 9.

${ }^{85} \mathrm{Id}$.

${ }^{86}$ Ruth Mason, Made in America for European Tax: The Internal Consistency Test, 49 B.C.L. REV. 1277, 1298 (2008). See, e.g., Case C-167/01, Kamer van Koophandel en Fabrieken voor Amsterdam v. Inspire Art Ltd., 2003 E.C.R. I-10155, बा 137-38, 143 (2003); Case C-212/97, Centros Ltd. v. Erhvervs-og Selskabsstyrelsen, 1999 E.C.R. I-1459, ๆ 26-27 (1999).

${ }^{87}$ See Case C-294/97, Eurowings Luftverkehrs AG v. Finanzamt Dortmund-Unna, 1999 E.C.R. I-7447, I 29 (1999). The Court rejected as a justification for higher taxation Germany's argument that the "lessor established in another Member State might be able to charge the lessee a lower rental because he is not liable to trade tax." Id.; see also Mason, supra note 86, at 1298 n.113-14.

${ }^{88}$ Mason, supra note 86 , at 1298 . "Thus, contrary to the arguments of some commentators, permitting tax discrimination when it does not result in a net tax disadvantage for the taxpayer may affect the common market by undermining tax competition." Id. 
inequitable. ${ }^{89}$ Additionally, "when the ECJ fails to recognize discriminatory taxes because they are obscured by advantages offered by other member states, the ECJ narrows the rights of EU nationals and allows the states to maintain distortive taxes that reduce social welfare." 90

As a matter of policy, the "EC Treaty's prohibition of nationality discrimination will only reinforce economic and political union to the extent that the Court recognizes and censures discrimination. Thus, it is crucial that the ECJ adopt a method of analyzing tax cases that will bring even obscure tax discrimination to light." $" 1$

\section{CONCLUSION}

There are markers of a federal system of finance, such as a national bankthe European Union Bank. But a common codified system of taxation-such as the 1916 Constitutional Amendment - perhaps through a directive or new multilateral treaty negotiation amongst the states could lead to such a system.

A Commerce Clause in the European Treaty system would provide a "federal" system of finance. This could be brought about through a directive or new multi-lateral treaty negotiation amongst the states could lead to such a system.

Indeed, either the European Union should adopt a true federal system - akin to that of the United States or avoid the issues of fiscal coherence all together for a non-common market. The Lochner-style-Kercharet-Morres-era hurts the unity of the "federal" system of the European Union.

The goal of this article is to show how the Kerckhaert-Morres approach has led to stagnation in the European market by allowing the competences of tax to be reserved by member states whereby causing a tension between the goal of a common internal market and the imposition of double taxation through separate taxing and discriminatory taxing regimes.

\footnotetext{
${ }^{89} \mathrm{Id}$.

${ }^{90} \mathrm{Id}$. at 1299.

${ }^{91}$ Id.
} 
